\title{
FARM ANIMAL GENETIC RESOURCES IN EGYPT: FACTSHEET
}

\author{
Salah Galal
}

Animal Production Department, Faculty of Agriculture, P.O. Box 68, Hadaeq Shubra 11241, Cairo, Egypt

\section{SUMMARY}

Egyptian and international literature shows that Egypt has got more than 60 local and derived breeds of livestock excluding exotic breeds. This enormous number of breeds needs to be verified and refined. Most of these breeds are named in an ad hoc manner according to their geographical location. Since there are only few discriminate characteristics to distinguish many of these breeds, proper phenotypic and genetic characterization is needed to be able to draw objective breeding plans for the utilization and possible conservation of some these valuable genetic resources. Aside from the two local rabbit breeds that have become extinct, Baladi White and Giza White, no local breeds seem endangered yet. However, Baladi cattle and local chicken breeds have suffered greatly from the introductions of exotic breeds due the indiscriminate crossing that usually follows these introductions. From 1991 to 2004, Baladi cattle have lost 19\% of their share in the national cattle herd. No figures are available for local chicken breeds but the trend is expected to be more alarming. Livestock production systems in Egypt are under pressure to increase output, especially of animal protein. This pressure is leading to an intensification of the system with little attention paid to sustainability and environmental elements. To monitor the state of animal genetic resources in the country animal census must take the breed into account, approximately initially until some breed standards have been established.

Stakeholder networking focused on the characterization and utilization of animal genetic resources is nearly totally absent in the country.

Keywords: Animal genetic resources, livestock, breeds, utilization, characterization, breed inventory, livestock production systems

\section{INTRODUCTION}

Farm animal genetic resources (FAnGR) are an integral part of the agricultural wealth in the country providing food and other agricultural products and services. Local FAnGR, i.e. those local breeds, landraces, strains and variety of animals, have developed over millennia adapting to specific local conditions and needs and they often constitute part of the country heritage and the basis for any livestock development. Egyptians have long appreciated animals in different ways ranging from adoring them as in ancient Egypt where the buck, the ram and the cow were sacred animals representing different gods in different parts of the country and used

Issued by The Egyptian Society of Animal Production 
as offerings to the gods (Khattab, 1986) to utilizing them in production and services. FAnGR, however, produce and provide services within a context of certain socioeconomic and physical environments that usually change over time. During the last half century, this change has greatly accelerated due to demographic, economic, social and technical-scientific developments. In many situations, changes in FAnGR could not cope with the changes in the production environment and what is required of them. The objective of this paper was to analyze the role of FAnGR in the agricultural and national economy of Egypt, chronicle the changing production environment, take stock of the present diversity in farm animals and attempt to offer a baseline for further studying this diversity.

\section{Land resources}

The most obvious feature in Egyptian land distribution is that the greatest part of the area is desert and that agriculture is nearly totally dependent on water from the Nile River. Egypt is indeed the gift of the Nile. Table 1 shows that of the total land area of $1,000,145$ ha only $3.43 \%(14,383,642$ feddan $)$ is agricultural land of which $14.66 \%$ is permanently covered mainly by poor plant cover due to the very low rainfall. Using Thornton et al. (2002) classification, the great bulk of livestock is produced under mixed irrigated humid/subhumid system. In the mixed farming system in Egypt, the crop rotation usually includes one third of the farm area as a winter fodder crop (mainly berseem, Trifolium alexandrinum). While the arable land area is $2,992,000$ ha, land is intensively cultivated with an average of more than two crops a year which would allow for the cultivation also of summer fodder crops. These fodder crops plus crop and industrial by-products constitute the bulk of feed resources. Good amounts of concentrate feeds and additives are imported for the intensive livestock production systems. The rangeland in the North Western Coastal desert and some part of Sinai falls under Thornton et al. (2002) classification of mixed rainfed arid/semi-arid where cultivation of barley and drought tolerant fruits and vegetables is practiced. These rangelands only partially sustain flocks and herds of sheep, goats and camels.

Table 1. Land use in Egypt, ha

\begin{tabular}{lr}
\hline \multicolumn{1}{c}{ Land Use } & Area \\
\hline Total area & $100,145,000$ \\
Land area & $99,545,000$ \\
Agricultural area & $3,424,000$ \\
Arable \& permanent crops & $3,424,000$ \\
Arable land & $2,922,000$ \\
Permanent crops & 502,000 \\
Non-arable\& non-permanent & $96,121,000$ \\
Agricultural area of land area & $3.43 \%$ \\
Arable land of land area & $2.93 \%$ \\
Permanent crops of land area & $0.50 \%$ \\
Permanent crops of agricultural area & $14.66 \%$ \\
\hline Source: FAOSTAT (2006)
\end{tabular}

Source: FAOSTAT (2006) 
Importance of livestock in Egyptian economy \& food security

In 2002, agriculture contributed $17 \%$ to the national GDP of Egypt while livestock alone contribution was $5 \%$, i.e. livestock contribution to the agricultural GDP was 29\% (FAOSTAT, 2005). The agricultural contribution to GDP rose from 6.3 billion $\$$ in $1979-1981$ period to 12 billion $\$$ in 2002 but its percentage contribution decreased from $21 \%$ to $14 \%$ during the same period due to the differential growth of other sectors of the economy (FAOSTAT, 2005). However, the contribution of livestock to agriculture remained around the figure of $30 \%$. To put the Egyptian figures in a regional perspective, the relative contribution of livestock to agriculture is the lowest among the Near East countries while its relative contribution to the national GDP , excluding oil producing countries, is only higher than Lebanon and Jordan (3\% and $1 \%$, respectively) but much lower than, say, Sudan (21\%). For the Near East region, the average contribution of agriculture to GDP in 2001 was $15 \%$, the average contribution of livestock to agriculture $15 \%$ and average contribution of livestock to GDP 6\% (World Bank, 2006 and FAOSTAT, 2005).

\section{Production}

Stock numbers of different species are shown in Table 2 and their development from 1996 to 2005 is in Fig 1. According to FAOSTAT (2006) stock numbers of ruminants increased substantially with a percentage increase ranging from $22 \%$ for sheep to $45 \%$ in cattle. Camel population went down by $8 \%$ during the same period. Numbers of ducks, turkeys and pigs remained more or less stable.

Table 2. Stock numbers in 2005, FAOSTAT (2006)

\begin{tabular}{crc}
\hline Species & Population & \% Change 1996-2005 \\
\hline Asses & $3,070,000$ & 3.0 \\
Buffaloes & $3,920,000$ & 34.9 \\
Camels & 120,000 & -8.1 \\
Cattle & $4,500,000$ & 44.8 \\
Chickens & $95,000,000$ & 39.7 \\
Ducks & $9,200,000$ & 8.2 \\
Geese & $9,100,000$ & 3.1 \\
Goats & $3,960,000$ & 26.5 \\
Horses & 62,000 & 50.6 \\
Mules & 1,150 & 15.0 \\
Pigs & 30,000 & 11.1 \\
Sheep & $5,150,000$ & 22.0 \\
Turkeys & $1,850,000$ & 27.6 \\
\hline
\end{tabular}




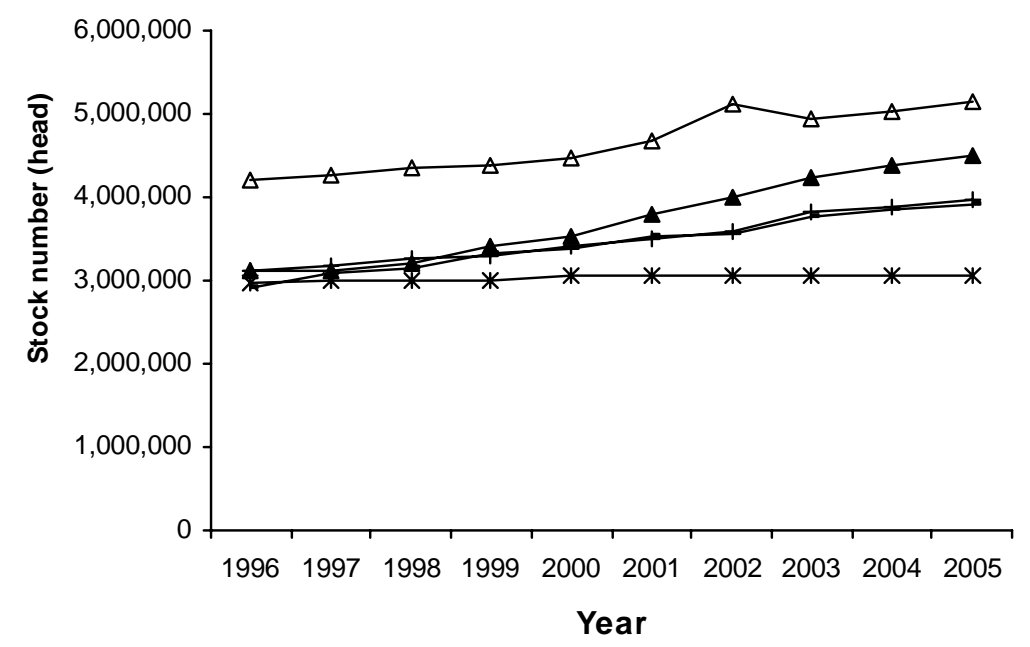

* Asses — Buffaloes $\longleftarrow$ Cattle $\multimap$ Goats $\_$Sheep

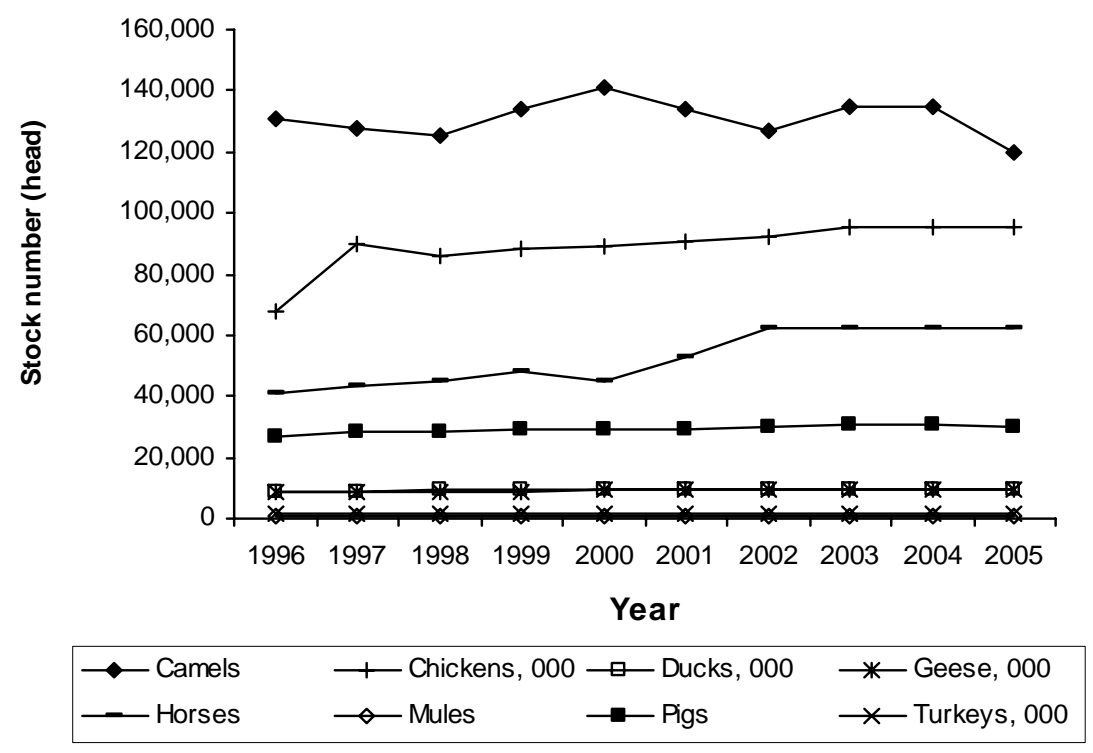

Fig 1. Stock numbers during 1996-2005, source (FAOSTAT, 2006) 


\section{Self-sufficiency in animals and animal products}

Figure 2 shows that the country has been net importer of animal products during the 1995-2004 period, let alone the import of good part of inputs required. Despite the steady increase in stock numbers and productivity, these increases could not meet the rising demand on animals and animal products. Most of the imports are beef, milk equivalent in terms of butterfat and live camels and sheep (Tables $3 \& 4$ ).
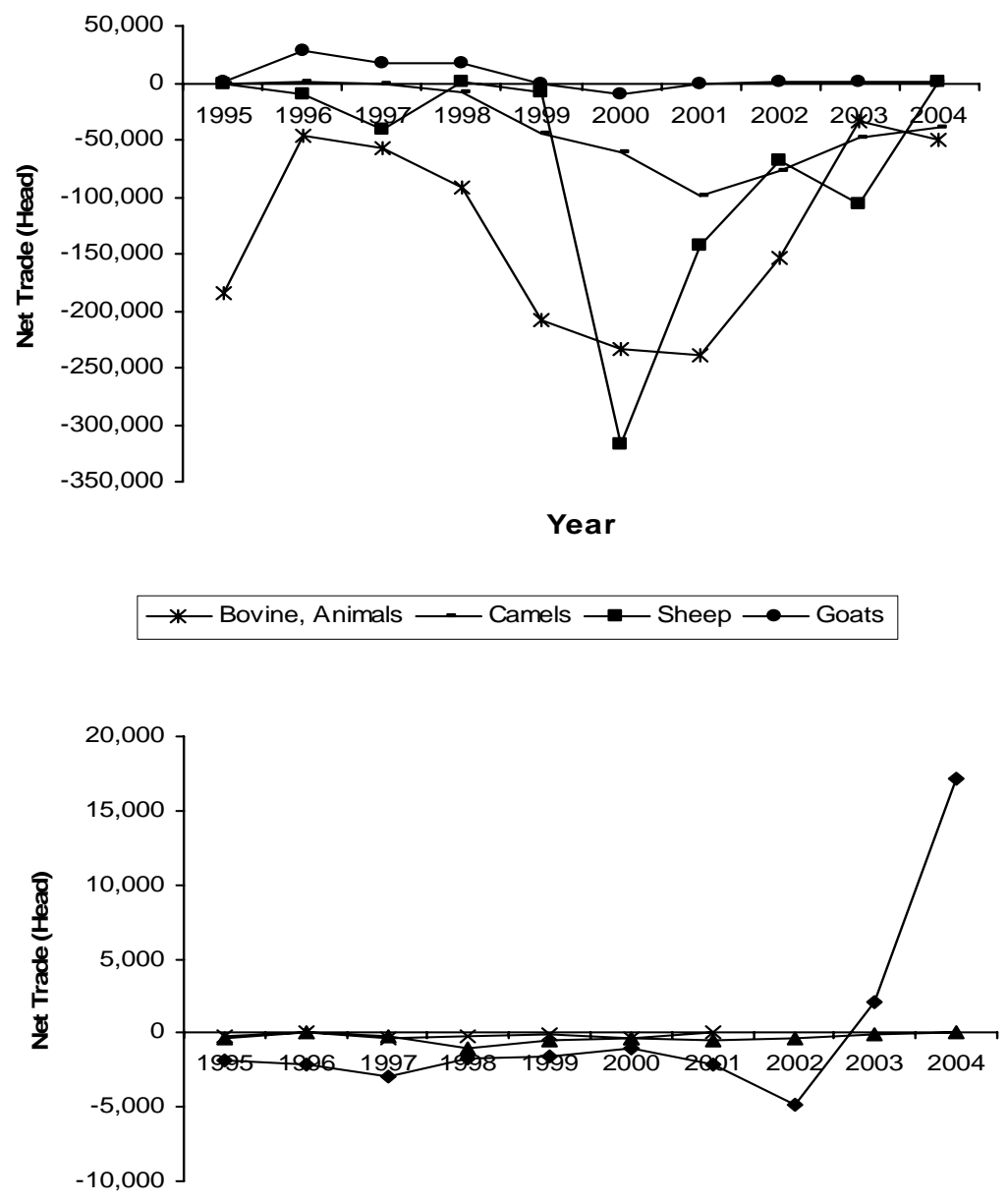

Year

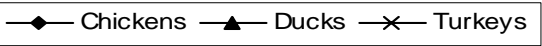

Fig 2. Net trade balance (export minus import) of live stocks. 
Table 3. Average 2002-2004 annual imports and trade balance (export minus imports) in livestock

\begin{tabular}{lr}
\hline Species & Net trade \\
\hline Bovine, head & $-79,096$ \\
Camels, head & $-55,258$ \\
Cattle, head & $-79,096$ \\
Chickens, 000 & 4,772 \\
Ducks, 000 & -152 \\
Goats, head & 476 \\
Rabbits, 000 & 2 \\
Sheep, head & $-58,241$ \\
Turkeys, 000 & 0 \\
\hline
\end{tabular}

Source FAOSTAT (2005)

Table 4. Average 2002-2004 imports, exports and net trade (exports minus exports) of main animal products, metric ton

\begin{tabular}{lrrr}
\hline Product & Imports & Exports & Balance \\
\hline Bovine meat & 133,123 & 555 & $-132,568$ \\
Eggs in the shell & 9 & 1,506 & 1,497 \\
Meat bovine fresh & 100,739 & 384 & $-100,356$ \\
Mutton and lamb & 395 & 79 & -316 \\
Milk equivalent & 580,943 & 45,985 & $-534,958$ \\
Milk fresh & 258 & 1,817 & 1,559 \\
Ovine meat & 395 & 82 & -314 \\
Poultry meat & 1,974 & 628 & $-1,345$ \\
Rabbit meat & 0 & 2 & 2 \\
Total meat & 135,621 & 1,346 & $-134,276$ \\
\hline Sourc
\end{tabular}

Source FAOSTAT (2005)

Egypt was net exporter over 2002, 2003 and 2004 in table eggs and showed favourable average trade balance in milk over the same years Fig (3). The per capita daily share of animal protein is approximately $19 \mathrm{~g}$ and that from plants is $76 \mathrm{~g}$. Table 5 shows latest figures available (2003, FAOSTAT, 2006) for average annual share of per capita of animal products. Estimates show that the average Egyptian diet is lopsided towards plant products. The average Egyptian over-ingests a total amount of calories of 3,356 a day (as compared to an adult average daily requirement of 2700 and 2000 for man and woman, respectively) including 94 grams of protein (as against an adult daily requirement of $56 \mathrm{~g}$ and 48 for average adult man and woman, respectively, WHO). Per capita annual consumption of ruminant meat has been more or less stable around $8.8 \mathrm{~kg}$ from bovine and 1.1 from small ruminants. The remarkable change has been in the increased consumption of poultry meat, milk, seafood and eggs. Table 6 shows the increase in 2003 relative to 1994. The shift from ruminant meat to poultry and fish meat is a trend dictated by the relatively cheaper prices for poultry and fish meat as compared to red meat and the latter ever 
increasing prices. Although mutton is considered a traditional meat in Egypt, it is becoming a product seasonally consumed during religious occasions and festivities. This forced preference changes would have considerable repercussions on the composition of genetic resources used for the production of these products.

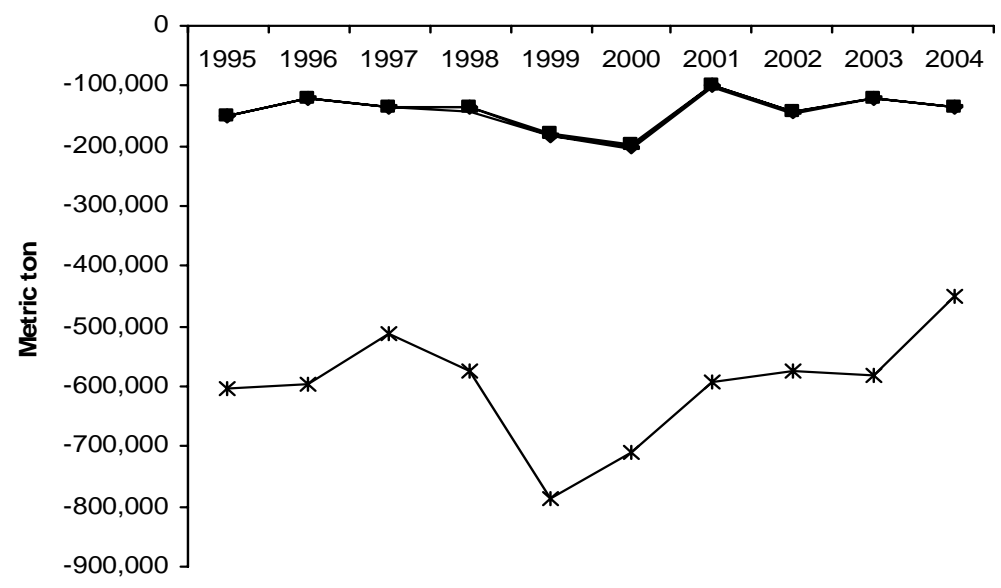

Year

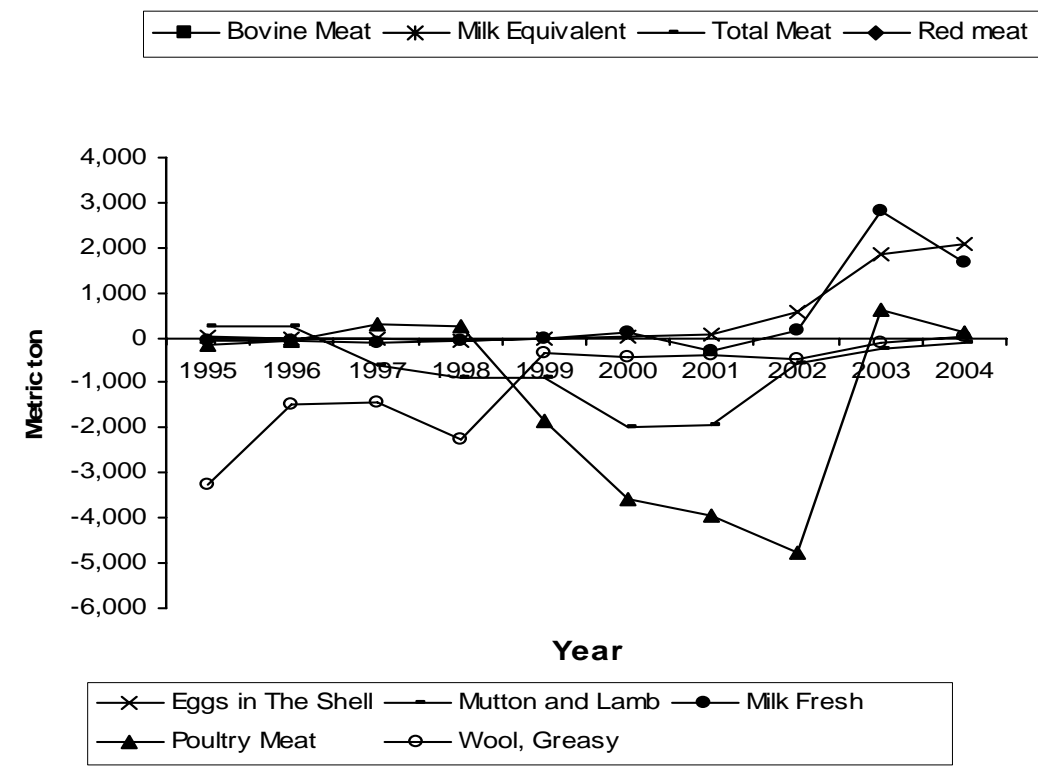

Fig 3. Net trade balance (export minus import) of main animal products 
Table 5. Average annual per capita share of main animal products (2003 estimates), $\mathrm{kg}$

\begin{tabular}{ll}
\hline Source & Amount \\
\hline Bovine meat & 8.8 \\
Sheep \& goat meat & 1.1 \\
Edible offals & 1.7 \\
Poultry & 9 \\
Milk & 62 \\
Eggs & 2.7 \\
Other meats & 1.8 \\
Fish-seafood & 14.7 \\
\hline
\end{tabular}

Table 6. Increase in per capita share in animal products showing significant increase during 1994-2003 period

\begin{tabular}{ll}
\hline Product & \% Change \\
\hline Fish \& sea food & 71 \\
Poultry meat & 69 \\
Milk & 58 \\
Eggs & 23 \\
\hline
\end{tabular}

"Livestock Revolution" (Delgado et al., 1999), i.e. increase in demand for animal products in developing countries, is actually happening in Egypt. During the period 1994-2003, where data is available from FAOSTAT (2006), human population increased in Egypt at an average rate of about 2\% annually while national consumption of meat increased at the rate of $3.4 \%$.

\section{Livestock production systems}

From a population perspective, the largest number of people is supported by mixed irrigated livestock production systems in the arid and semi-arid areas of the country. Almost two-thirds of the people live in this system (Seré and Steinfeld, 1996). The main animal production systems in the country are summarized as follows:

a- Non-intensive (extensive or desert) production system. This system depends on grazing natural rangelands totally dependent on rain. Sheep, goats and camels are the species raised under this system. These animals provide the main source of income to the population living in these areas and play an important social and economic role. Currently, the range in this system does not provide more than one third of livestock present and it has been more and more dependent on concentrate feeds especially during the dry season. Males are with females all year round but mating is concentrated in June-July so that lambing/kidding takes place during pasture growth. Camels are usually mated in October to March. This system is prevalent mainly in three geographical regions: 
i- Sinai. Rainfall ranges between 100-200 mm annually during November to March. Range is usually poor and includes annuals and perennial shrubs. Sheep and goats represent $95 \%$ of livestock in the Peninsula whose breeds have not been characterized to any extent. Sinai Black goat is the predominant goat breed but there are also a scattered number of Damascus goats.

iii- North West Coast. This region extends from west of Alexandria to the borders with Libya, nearly $480 \mathrm{~km}$ long and a width ranging from 25 to $60 \mathrm{~km}$ from the coast. Rainfall ranges between 100 and 170 mm annually mainly during November-March. Agricultural activities include horticulture (fig, olive, and almond) and growing barley but lately the State has been encouraging wheat planting in some areas to replace barley. Sheep followed by goats are the most common species and the ratio between the two varies with the rain condition and the market. Often, during summer some herds/flocks travel to adjacent areas in the delta to graze stubbles and aftermath. Flock/herd size is between 50 and 200 but it can reach thousands in a few instances. Lambs are fattened on barley and concentrate supplement bought in the valley. Barki sheep and Barki goats are the breeds raised under that system. Much of the strip adjacent to the Mediterranean cost which has the highest rainfall is no longer accessible for grazing due its transformation into resort areas.

iii- Shalateen-Halaieb-Aburamad Triangle. This region lies between the Nile valley in the west and the Red sea in the east shaping as a triangle with its base at the Sudanese borders. Rainfall ranges between 80 and $100 \mathrm{~mm}$ annually during NovMarch. Camels coming from Sudan are very common in this area. Sheep represent $52 \%$ of the total livestock, camels $26 \%$ and goats $22 \%$. This system is gradually shifting towards intensification due to the shortage of pasture and the increased demand on animal products.

Nomadism has nearly vanished in this system but some transhumance still exists.

$\boldsymbol{b}$ - Semi-intensive production system. This system is common in the Nile delta and valley. The system is characterized by small holdings with 1-2 head of large ruminants (cattle and buffalo) and 2-5 small ruminants. Animals raised under this system are mainly of local breeds and represent $80 \%$ of the total national livestock. In this system milk is mainly produced from buffaloes, fresh or processed for sale and family consumption. Meat is a by-product from buffaloes where calves are usually sold at very young age to save milk. Many successful projects were implemented to fatten buffalo calves to mature body weights but these projects have been in phases of interruption and resumption due to the financing circumstances. Local cattle are raised mainly for meat. Animals are fed on fodders, stubbles, by-products, and concentrates. Cattle and buffaloes were used as work animals in this system but at present they are rarely used for that purpose. Inputs of this system are relatively low while the output is medium.

c- Intensive production system. Milk produced from commercial dairy herds represents about $10 \%$ of national production. Dairy farms are usually based on buffaloes and Holstein/Friesian or crossbred cattle. These farms are common in the delta and its desert fringes. Larger commercial dairy farms usually have Holstein stocks with the size of herd ranging from 200 to 500 cows plus their followers. Such farms are managed by highly experienced staff and often manufacture their feed stuffs. Fattening operations (both for buffalo and cattle calves) are two categories, the 
first grows calves from weaning (100-125 kg) to $200-220 \mathrm{~kg}$ and the second fattens them up to $350-450 \mathrm{~kg}$ depending on the species and genetic makeup. Fattening lambs and kids is common all over the country. Grains are the main ingredient in their fattening rations. Lamb and kid fattening is profitable with an economic return up to $37 \%$. Lamb and kids are sometimes exported to the Gulf States where there is a good demand on them and they are also fattened for special religious and social occasions where they command high prices. Milk production is mainly from cattle (mainly exotics and their crossbreds with the local) and buffaloes. In 2004 cattle produced $48 \%$ of total milk production in the country while buffaloes produced the rest of 52\% (Ministry of Agriculture and Land Reclamation, 2005). Sheep and goat contribution to the national milk production is very little.

d-Peri-urban production system. Some producers keep small herds in the fringes of cities (Zarraba) making use of accessible adjacent markets. Milk is the main product from such herds where the young are sold for fattening. Other species (sheep, goats, pigs and poultry) are also raised commercially in peri-urban neighbourhoods. Despite the relative economic importance of this system, there exists very little information about it.

$\boldsymbol{e}$ - Poultry production system. Poultry production has gone through great changes in the last fifty years. It has evolved from the rural/backyard production system to an industrial one with many integrated units. The commercial poultry sector is owned by private sector, coops and public sector. But the latter's share has shrunken greatly which led to an increase in the efficiency of production. A typical commercial economically functioning chicken production farm is $500 \mathrm{~m}^{2}$, enough to raise 5000 birds in one cycle. This industry depends to great extent on imported inputs, the thing which often has had negative impact. The rural sector produces $25 \%$ of the broilers (100 million birds) while the commercial sector produces the rest $(75 \%, 300$ million birds). Of the production of the commercial sector $70 \%$ is contributed by large corporations while the remaining $30 \%$ is produced by small-scale producers (Ministry of Agriculture and Land Reclamation and FAO, 2003). The rural sector produces 2000 million table eggs annually while the share of the commercial sector is 4800 million eggs of which $90 \%$ by large conglomerates and $10 \%$ by small producers. Large companies import their needs of parent and grandparent stocks either for broiler or table egg production. The rural sector is almost the sole provider of ducks and geese. Some commercial units produce ducks of different breeds, Muscovey, Peking and Mallard while the rural sector produces local breeds. There are some commercial turkey farms but they usually produce seasonally. There is little demand on turkey meat because of its high prices. The rural sector plays little role in turkey production. There used to be large rabbit farms using imported breeds like New Zealand and California but their number have dwindled greatly due to the increase in input costs. The rural sector contributes $90 \%$ to the total rabbit production. Poultry production has been hit hard with the spread of the avian influenza pandemic in the winter and spring of 2006 continuing through 2007. All sectors of the industry have greatly suffered but the backyard system has suffered the most. 
Egypt is known in the region for its pigeon production. Production is in towers, reminiscent of ancient Egypt, where birds free-range but are supplemented with grains in the towers. Egypt exports pigeons to Mediterranean and Gulf countries.

f- Equine production system. Population of donkeys is sizable (3.1 million in 2005) which indicates their economic importance but there is not much information on them or their production system. They are used only for riding and for transport. The rural sector is the sole producer of donkeys. Average holding among farmers is between one and two donkeys. There exist farms specializing in Arabian horse breeding; some are internationally famous for their pedigreed Arabian stocks. Horses are used locally for leisure, riding and transport.

g-Swine production system. Swine production is not common in Egypt. Pig farms are concentrated nearby garbage pits at the edges of cities under often non-hygienic production conditions. Their meat is sold in special shops in larger cities.

Generally, it can be safely concluded that during the last two decades or so the livestock production systems in Egypt have consistently been moving towards intensification. Some of the reasons for this trend towards intensification are:

- Overstocking degraded the rangelands to a great extent.

- Due to the limited land area efforts have always been to maximize output per unit area and recently per unit of water which is becoming scarcer with time.

- The fast growing population and the rising standard of living forced the State to look for a "quick fix" for the shortage in animal protein. With a lack of long-term vision for the role of local breeds and plans for their development along with the globalization of trade in breeding material (Hoffmann and Scherf, 2004) and the vigorous efforts of export/import breeding firms, meeting the rising demand for animal products was done through direct import of animals and animal products for consumption as well as herd establishment, concentrating on the introduction of dairy breeds and commercial poultry industry. Such actions had their repercussions on the local animal genetic resources especially in these two species, i.e. cattle and chickens.

- Subsidies for feed, grains and concentrate that prevailed in 1990's and are still offered in some way encouraged producers to intensify their production system.

Trends in the animal production systems, beside the intensification of the production system, are sedentization of sheep and goat production systems and commercialization of dairy and poultry production systems. The impact of this on breed structure in sheep and goats is not much but impact is great on poultry and cattle breeds where local breeds are declining in importance. Landless peri-urban livestock production system is where medium size cattle and poultry production units are springing up around major cities. Ministry of Agriculture and Land Reclamation and FAO (2003) give details of changes of livestock production systems of different species.

\section{Genetic resources}

Table 7 shows a comprehensive list of livestock breeds in Egypt collected from national and international literature, mainly FAO. The "breed" definition used in this 
study is that of FAO (Scherf, 2000), that it is a socio-cultural entity. A due qualification for Table 7 is that many breeds may not actually exist or may just be another name of some breed, or just a breed named after some geographical distribution. These are all possible cases but the basic philosophy behind making this table is that breed names are taken as they are found in the literature and the list should remain so until otherwise shown by some analytical work that some of these breeds are in fact the same or even fictitious. A live example of that is that buffalo breeds were arbitrarily named after their geographic location. There was no convincing evidence that they are actually different genetic entities until a recent study by the Faculty of Agriculture, Ain shams University and the Animal Production Institute (Elbeltagy, 2006) using DNA techniques showed that indeed the Saeidi buffalo is a distinct breed from other "breeds" in the Nile delta.

Table 7. Comprehensive list of local livestock breeds in Egypt

\section{Species Breed common name Other names/spelling}

\begin{tabular}{lll}
\hline Ass & Hassawi & \\
Ass & Saeidi & \\
Ass & Egypt Baladi & Saiedi \\
Buffalo & Saidi & Egypt Baladi (= local), Monoufi \\
Buffalo & Minufi & Egypt Baladi (= local), Beheiri \\
Buffalo & Beheri & Beheri, Menufi (varieties but also synonyms), \\
Buffalo & Egypt Baladi (=local) & Monoufi \\
& & Egypt Baladi (= local) \\
Cattle & Menufi & Arabian (Eng.) \\
Cattle & Maryuti & Domiatta, Domiatti, Domyati, Dumiati, \\
Cattle & Damietta & Dumyati, Domiati \\
& & Saeidi \\
Cattle & Saeidi & \\
Chicken & Inshas & \\
Chicken & Hawara & \\
Chicken & Mandarah & \\
Chicken & Matrouh & \\
Chicken & Gimmizah & \\
Chicken & Silver Montazah & \\
Chicken & Golden Montazah & \\
Chicken & Sinai & \\
Chicken & Alexandria & \\
Chicken & Salam & Montazah Silver \\
Chicken & Dhicken & Dandarawi \\
Chicken & Bahig & \\
\hline
\end{tabular}


Table 7. Cont.

\begin{tabular}{|c|c|c|}
\hline Species & $\begin{array}{l}\text { Breed common } \\
\text { name }\end{array}$ & Other names/spelling \\
\hline Dromedary & Fellahi & \\
\hline Dromedary & Sudani & \\
\hline Dromedary & Mowalled & Muwallad \\
\hline $\begin{array}{l}\text { Duck } \\
\text { (domestic) }\end{array}$ & Sudani & \\
\hline $\begin{array}{l}\text { Duck } \\
\text { (domestic) }\end{array}$ & Shersheer & \\
\hline $\begin{array}{l}\text { Duck } \\
\text { (domestic) }\end{array}$ & Domiati & \\
\hline Goat & Barki & Sahrawi (= of desert) \\
\hline Goat & Saidi & Saeidi, Egypt Baladi (= local) \\
\hline Goat & Sharkawi & \\
\hline Goat & Zaraibi & Egyptian Nubian (Eng.), Nuba, Theban \\
\hline Goat & $\begin{array}{l}\text { Wahati (Arabic }= \\
\text { related to oases) }\end{array}$ & Egypt Baladi (= local) \\
\hline Goat & $\begin{array}{l}\text { Abouramad- } \\
\text { Halaieb- } \\
\text { Shalateen (AHS) }\end{array}$ & \\
\hline $\begin{array}{l}\text { Goose } \\
\text { (domestic) }\end{array}$ & Masri & \\
\hline Horse & Egyptian (Eng.) & $\begin{array}{l}\text { Egypt Baladi (= local) (general name given to } \\
\text { all horses in Egypt) }\end{array}$ \\
\hline Pig & Egypt Baladi & \\
\hline Pigeon & Baladi & \\
\hline Pigeon & Roumi & \\
\hline Pigeon & Qattawi & \\
\hline Pigeon & Maltese & \\
\hline Rabbit & Galabi (Arabic) & \\
\hline Rabbit & $\begin{array}{l}\text { Egypt Baladi } \\
\text { White (Eng.) }\end{array}$ & \\
\hline Rabbit & Matrouh Gabali & \\
\hline Rabbit & Sinai Gabali & \\
\hline Rabbit & $\begin{array}{l}\text { Egypt Baladi } \\
\text { Black (Eng.) }\end{array}$ & \\
\hline Rabbit & $\begin{array}{l}\text { Egypt Baladi } \\
\text { Red (Eng.) }\end{array}$ & \\
\hline Rabbit & $\begin{array}{l}\text { Giza White } \\
\text { (Eng.) }\end{array}$ & \\
\hline Sheep & Saeidi & Saiedi \\
\hline Sheep & Maenit & \\
\hline Sheep & Kanzi & \\
\hline Sheep & Farafra & \\
\hline
\end{tabular}


Table 7. Cont.

\begin{tabular}{lll} 
Species & $\begin{array}{l}\text { Breed common } \\
\text { name }\end{array}$ & Other names/spelling \\
\hline Aboudleik & \\
Barki & Egypt Baladi (= local), Fellahi (= peasant) \\
Fellahi & Ibeidi & Ibidi \\
Kurassi & \\
Ossimi & Meraisi, Ausimi \\
Rahmani & \\
Seep & Saidi & Sohagi \\
Sanabawi & \\
Ebeidi & & \\
Mahalla 85 & &
\end{tabular}

Annex I shows remarks about these breed, if any, arranged alphabetically regardless of the species.

Egypt also has and has had many transboundary breeds some of which took roots in the country, others that are still within experimental stations and others that disappeared as distinct breeds but my have left some of their genetics in the local breeds. The main transboundary breeds in the country are:

Cattle:

Abondance $^{2}$, Brown Swiss ${ }^{2}$, Friesian ${ }^{1}$, Holstein $^{1}$, Jersey $^{1}$, Simmental $^{2}$, Tarentaise $^{2}$

Chickens:

Commercial strains/synthetics, Leghorn ${ }^{1}$, Plymouth Rock $^{1-2}$, Rhode Island Red ${ }^{1}$

Ducks:

Khaki Campbell ${ }^{2}$, Muscovey ${ }^{1}$, Pekin ${ }^{1}$,

Goats:

Alpine $^{2}$, Anglo Nubian $^{2}$, Damascus $^{1}$

Horses:

Thoroughbred ${ }^{2}$

Pigeon:

King, Carneon, Homer, Mondaine, Runt

Rabbits:

Bouscat $^{1}$, California ${ }^{1}$, New Zealand ${ }^{1}$

Sheep:

Awassi $^{2}$, Chios ${ }^{2}$, Finnish Landrace ${ }^{2}$, Hmapshire ${ }^{2}$, Lacaune ${ }^{2}$, Leicester ${ }^{2}$, Merino (different types and origins) ${ }^{2}$, Romanov ${ }^{2}$, Suffolk $^{2}$

Turkeys:

Broad Breasted Bronze ${ }^{1}$, Commercial strains ${ }^{1}$, Nicholas ${ }^{1}$

Two rabbit breeds have become extinct: Baladi White and Giza White.

\footnotetext{
${ }^{1}$ Breeds that took root in the country and became integrated into production systems

${ }^{2}$ Breeds brought in for experimental purposes, with bilateral aid but have not integrated into production system or present on a limited scale
}

Formatted: English 


\section{Populations}

Official national livestock census does not take count of the breed. It considers only species, gender, and age class, and in cattle crossbred versus local. So none of the listed breeds is with known population size except probably Barki sheep and Barki goats where their habitat coincides almost exactly with geographically delineated region, i.e. the North Western Coastal Desert or Matrouh Governorate (but this also includes Siwa oasis). Small ruminant population in Matrouh governorate in 2004 was 577,227 and 170,272 for sheep and goats, respectively (Ministry of Agriculture and Land Reclamation, 2005). Extrapolated numbers for other small ruminant breeds are reported in Galal et al. (2005). Accurate estimates of the population size of different breeds are important to be able to determine whether a breed is endangered and the risk status of the breed. So far, no animal breed seems to be endangered in Egypt, notwithstanding the two rabbit breeds that are already extinct.

\section{Origin of breeds in Egypt}

The present-day local cattle breeds are mainly Bos torus (Eng) in contrast to the Hamitic Longhorn Bos primigenius opisthonomus (Lat.), Ancient Egyptian (Eng.), Egyptian Longhorn (Eng.) original from African aurochs, Original of West African longhorns and (with zebu) of Sanga that are depicted in ancient Egyptian murals and engravings. While the present-day fat-tailed Egyptian sheep relate to West Asia sheep with only little resemblance to Ancient Egyptian (Eng.) Hamitic Longtailed (Eng.) and Ovis longipes palaeoaegypticus origin of African long-legged in some Southern Egypt population. Goats are prehistoric in Egypt. There were two goats, hircus mambrinus and hircus thebaicus (Khattab, 1986) in ancient Egypt while the present-day goat in Egypt is Caprae hircus.

The origin of a breed can be broadly classified as either "local" or "imported" or in case where the origin is not known as "undefined". There is a great number of breeds imported but could not adapt to the local production environments. These are mainly sheep breeds and to some extent cattle. Starting early in the $19^{\text {th }}$ century many sheep breeds were imported for experimentation as well as for flock establishment. The great majority of these introductions failed (Galal, 1987).

\section{Risk status of breeds in Egypt}

All breeds presently existing in Egypt can be listed within the category "not at risk", notwithstanding the two extinct rabbit breeds. Definition of different degrees of risk status is given in Scherf (2000). However, as previously pointed out, assessing and monitoring the risk status accurately can only be made when population sizes are known, information which Egypt does not have. However, trends of genetic erosion in local cattle and poultry genetic resources could be alarming. Fig. 4 shows that the percentage of Baladi cattle has been decreasing and the crossbred is on the increase while exotics are more or less constant. In 1991 Baladi, crossbreds and exotics share of the total cattle population was $77 \%, 19 \%$ and $4 \%$, respectively. In 2004 these figures were $62 \%, 34 \%$ and $4 \%$, respectively, i.e. in 13 years the decline of the Baladi cattle number is 19\% (Ministry of Agriculture and Land Reclamation, 1992 to 2005). The introgression of exotic genes into Baladi cattle is partly planned but 
mostly indiscriminate because of surplus males from farms with exotic breeds going to local markets as well as F1 and later generations of crossbred males and females from planned crossbreeding projects are used for breeding. General observation and the production systems prevailing in poultry and rabbit industry indicate that the situation regarding local breeds could be even griever but there are no figures to substantiate such observation. National efforts made to conserve local chicken breeds, e.g. Fayoumi; through utilization is a good example for maintaining farm livestock biodiversity. Purebreeding of exotics in sheep and goats did not take root to any serious degree that may endanger local breeds and the same is said about buffalo despite some attempts/contemplations to introduce germplasm from other countries.

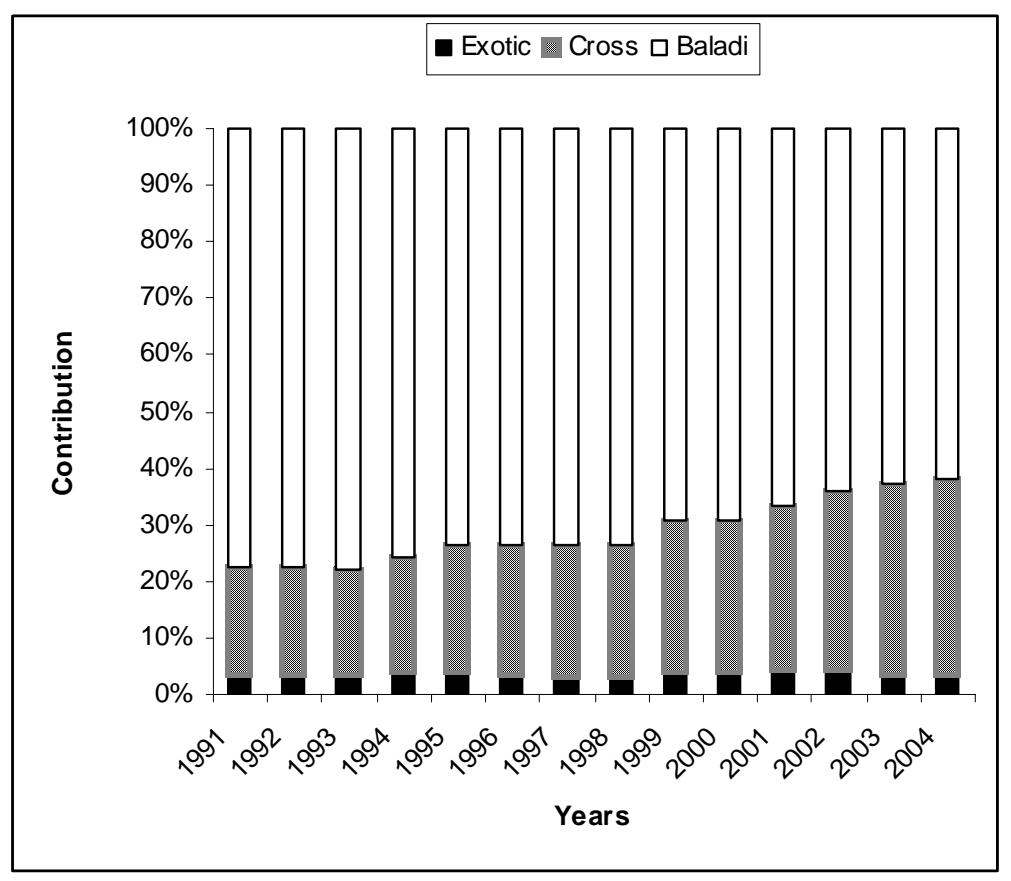

Fig. 4. Percentage representation of Baladi, crossbred and exotic of the total Cattle population from 1991 through 2004.

\section{Areas of concern regarding AnGR \\ Changing functions}

With the wide spread of the machineries and the more dependence on inorganic fertilizers, the status of work animals suffered greatly. Native cattle received much less attention. Horses sustained their status for their aesthetic, leisure and along with asses they are still used widely for riding and transport. The camel is still used for village and desert transport but its use is declining. 


\section{Threats to Animal Genetic Resources (AnGR)}

AnGR most at risk are local cattle and poultry breeds. These breeds had been under selection, mainly natural, for different breeding objectives from what is required from them now. Little effort was made to define the role of these breeds in a changing situation. Since the main driving force in livestock developments in Egypt is to provide animal protein to meet the growing demand in the short run, this has been done often with little consideration for environment and sustainability factors. In this context local breeds are sometimes wrongly thought of as something of the past. However, there is rising awareness of their importance especially in situations where introduction of exotics has resulted in failures. For example in many herds in Egypt the average lactation milk yield in Friesian cows is less than one third of its genetic potential. Exotic breeds have an important role to play in increasing national production but their use must be rationalized and the proliferation of their genetics must be under control.

The most serious factors negatively impacting AnGR are the introduction of exotic breeds and the indiscriminate crossing that accompanies this introduction, and loss of function. The introduction of dairy cattle breeds, especially Friesian and Holstein, has greatly impacted local cattle breeds while the introduction of New Zealand and California rabbit breeds in Egypt has led the disappearance of two local rabbit breeds. The loss of function negatively affected cattle, equines, and to some extent camels.

Disease, especially zoonotics, situation has greatly impacted the livestock industry but only in the short run. Its impact on AnGR is still to be evaluated in the long run. During the BSE crisis in Europe and elsewhere consumption shifted from cattle to camels, poultry, small ruminants and buffalo meat. The impact of the recent pandemic of avian influenza in the winter and spring of 2006 through 2007 on avian genetic resources is still to be assessed. The Act by the government that all backyard and free ranging poultry production systems must be greatly modified or abandoned could negatively impact local breeds which provide the main bird for such production systems. Such abandonment has got gender and poverty-alleviation issues as well, which must be addressed.

Urbanization, rising education level and changing lifestyle are contributing to changes in livestock production systems. Younger generations are less anxious to work as shepherds or animal keepers.

\section{State of institutional capacity to manage animal genetic resources}

Egypt greatly lacks on institutions managing AnGR. There exist institutions catering for livestock production per se but not directly involved in AnGR management. There is lack of appreciation that while AnGR is an integral part of livestock production in general it is a field of a special nature requiring multidisciplinary orientation and networking. Lack of institutional capacity in the country is evident from the following:

- Virtually no breed associations in the conventional sense exist in the country except for fanciers like that of the pigeon breeders. There are buffalo and cattle associations but they fall under "utility associations" providing production 
services for their members but do not keep herdbooks or run performance recording nationwide.

- Role of NGOs and different stakeholders is absent or minimal at best, especially farmers.

- Absence of national recording systems.The existing recording takes place in state farms and some isolated herds and flocks.

- Egypt has not established an effective National Focal Point or an actively involved National Coordinator in the manner detailed out by FAO AnGR Management Program, let alone the Regional Focal Point. There has been an agreement with the International Center for Agricultural Research in the Dry Areas (ICARDA) to host the Regional Focal Point but it is still to be seen as an active player.

- No real or virtual institutional structures exist in the county whose main concern is AnGR management in its entirety, i.e. breed identification, breed characterization, breed development, breed surveying, monitoring and determination of risk status, and breed conservation.

- Lack of short- and long-term policies for the management of AnGR in the country.

Training in all aspects of AnGR management is needed, more specifically,

- Systematic characterization, both phenotypic and genetic

- Genetic evaluations: evaluation of crossing experiments, estimation of breeding value

- Molecular genetics techniques

- Embryo transfer and related technologies, e.g. MOET, and artificial insemination

- Networking

- Establishing national recording system

- AnGR conservation

- Establishing effective gene banks

- Networking different livestock stakeholders

However, there exist in Egypt institutions capable of offering a reasonable level of training in many aspects of the above mentioned needs but this requires commitment, coordination and national networking.

\section{Legislations}

There are many legislations in Egypt dealing with livestock in general, i.e. hygiene, slaughterhouses, quarantine etc, but very little that deal with AnGR management in specific. Legislations are needed for the regulation of the use of exotic and local germplasm especially in cattle and poultry.

\section{REFERENCES}

Delgado, C., M. Rosegrant, H. Steinfeld, S. Ehui, C. Courbois, 1999. Livestock to 2020: the next food revolution. Food, Agriculture, and the Environment Discussion Paper No. 28, IFPRI, Washington, U.S.A., pp 72. 
Elbeltagy, A., 2006. Genetic characterization of some local Bos Bubalus bubalis types using molecular techniques. PhD Thesis, Faculty of Agriculture, Ain Shams University, Cairo, Egypt, pp 93.

FAOSTAT, 2005. 2005. CD, FAO, Rome, Italy

FAOSTAT, 2006. http://www.fao.org, accessed in May 2006.

Galal, Salah, 2005. Small Ruminant Breeds of Egypt. In: Characterization of Small Ruminant Breeds in West Asia and North Africa, Vol 2: North Africa, ICARDA, Aleppo, Syria, 140-193.

Galal, Salah, 1987. Sheep and goat production research in Egypt. 1987. In Small Ruminants in the Near East, Editor A.W. Qureshi and H.A. Fitzhugh, FAO Animal Production Health Paper No. 54, FAO, Rome: 117.

Hoffmann, I and B. Scherf, 2005. Management of animal genetic diversity. In: Animal Production and Animal Science Worldwide, WAAP Book of the Year 2005, A. Rosati, C. Tewolde and C. Mosconi, Ed, World Association for Animal Production, Wageningen Academic Publisher, The Netherlands, pp 221-246.

Khattab, H.A, 1985. Livestock in Ancient Egypt. General Directorate for Agricultural Culture, pp 224 (in Arabic).

Ministry of Agriculture and Land Reclamation and FAO, 2003. First Report on the State of Animal Genetic Resources in the Arab Republic of Egypt. FAO, Rome, pp 55.

Ministry of Agriculture and Land Reclamation. Economic Affairs Sector, 1992 to 2005. Study of Most Important Statistical Parameters of Animal, Poultry, Fish and Apiculture Wealth. Volumes 1 to 10.

Ministry of Agriculture and Land Reclamation and FAO, 2003. First Report on the State of Animal Genetic Resources in the Arab Republic of Egypt, FAO, Rome, pp 58.

Scherf, Beate. (Ed). 2000. World Watch List for Domestic Animal Diversity, $3^{\text {rd }}$ Ed. FAO, Rome, pp 575.

Sere, C., and H. Steinfeld, 1996. World Livestock Production Systems. Anim. Prod. and Hith Paper No. 127. FAO, Rome, Italy, 82 pp.

Thornton, P.K., Kruska, R.L. Henninger, N., Kristjanson, P.M., Reid, R.S. Atieno, F.A., N. Odero, T. Ndegwa, 2002. Mapping Poverty and Livestock in the Developing World. International Livestock Research Institute, Nairobi, Kenya. http://www.ilri.cgiArabicorg/InfoServ/Webpub/fulldocs/mappingPLDW/index.ht $\underline{\mathrm{m}}$, June 2006.

WorldBank.2006.

http://devdata.worldbank.org/external/CPProfile.asp?SelectedCountry=EGY\&CC $\underline{\mathrm{ODE}}=\mathrm{EGY} \& \mathrm{CNAME}=\mathrm{Egypt} \% 2 \mathrm{C}+\mathrm{Arab}+$ Rep.\&PTYPE$=\mathrm{CP}$, July 2006 
Annex I. Remarks on local livestock breeds in Egypt and their origin, alphabetically ordered regardless of species

\begin{tabular}{|c|c|c|}
\hline Breed & Species & Origin \\
\hline Aboudleik & Sheep & Locally adapted breed \\
\hline AHS & Goat & $\begin{array}{l}\text { Locally adapted breed. Goats in Abouramad-Halaieb- } \\
\text { Shalateen Triangle. }\end{array}$ \\
\hline Alexandria (Eng.) & Chicken & \\
\hline $\begin{array}{l}\text { Bahig } \\
\text { Baladi }\end{array}$ & $\begin{array}{l}\text { Chicken } \\
\text { Pigeon }\end{array}$ & autochthonous, derived breed. \\
\hline Barki & Goat & $\begin{array}{l}\text { This breed similar to Libyan and originated in the } \\
\text { north-western coastal desert of Egypt and is the } \\
\text { smallest among the native breeds (Egypt Baladi, } \\
\text { Nubi). }\end{array}$ \\
\hline Barki & Sheep & \\
\hline Beheri & Buffalo & Variety of Egypt Baladi \\
\hline Damietta & Cattle & Variety of Egyptian cattle \\
\hline Dandarawi & Chicken & Locally adapted breed. \\
\hline Domiati & $\begin{array}{l}\text { Duck } \\
\text { (domestic) }\end{array}$ & \\
\hline Ebeidi & Sheep & Locally adapted breed \\
\hline Egypt Baladi & Ass & Variety of Egyptian \\
\hline Egypt Baladi & Pig & Locally adapted breed \\
\hline $\begin{array}{l}\text { Egypt Baladi }(= \\
\text { local) }\end{array}$ & Buffalo & \\
\hline $\begin{array}{l}\text { Egypt Baladi } \\
\text { Black (Eng.) }\end{array}$ & Rabbit & $\begin{array}{l}\text { Cross-breeding was practised for several generations } \\
\text { between Egypt Baladi (native) rabbits and Giant } \\
\text { Flander (exotic breed) in stations of Poultry Breeding, } \\
\text { Ministry of Agriculture .Heavy does ( } 50 \% \text { Giant / } \\
50 \% \text { Baldi) were backcrossed with Giant }\end{array}$ \\
\hline Egypt Baladi Red & Rabbit & $\begin{array}{l}\text { Cross-breeding was practised for several generations } \\
\text { between Egypt Baladi (native) rabbits and Giant } \\
\text { Flander (exotic breed) in stations of Poultry Breeding, } \\
\text { Ministry of Agriculture .Heavy does ( } 50 \% \text { Giant / } \\
50 \% \text { Baladi) were backcrossed with Giant }\end{array}$ \\
\hline $\begin{array}{l}\text { Egypt Baladi } \\
\text { White }\end{array}$ & Rabbit & $\begin{array}{l}\text { Cross-breeding was practised for several generations } \\
\text { between Egypt Baladi (native) rabbits and Giant } \\
\text { Flander (exotic breed) in stations of Poultry Breeding, } \\
\text { Ministry of Agriculture .Heavy does ( } 50 \% \text { Giant / } \\
50 \% \text { Baldai) were backcrossed with Giant }\end{array}$ \\
\hline Egyptian (Eng.) & Horse & \\
\hline Farafra & Sheep & $\begin{array}{l}\text { Locally adapted breed. Farafra, an oasis in the } \\
\text { western desert of Egypt, is the habitat of this breed. }\end{array}$ \\
\hline Fellahi & Dromedary & \\
\hline Fellahi & Sheep & $\begin{array}{l}\text { Not very distinct, maybe a composite of Ossimi, } \\
\text { Rahmani and other breeds }\end{array}$ \\
\hline Galabi (Arabic) & Rabbit & \\
\hline
\end{tabular}


Annex I. Cont.

\begin{tabular}{|c|c|c|}
\hline Breed & Species & Origin \\
\hline Gimmizah & Chicken & $\begin{array}{l}\text { This is a cross between the White Plymouth Rock } \\
\text { (WPR) and Dokki4 and has been developed at } \\
\text { Gimmizah Poultry Research Station of APRI, Ministry } \\
\text { of Agriculture. It is named after Gimmizah village of } \\
\text { Gharbia Province in Delta and has been stabilized over } \\
10\end{array}$ \\
\hline Giza White (Eng.) & Rabbit & $\begin{array}{l}\text { In 1932, a native stock of rabbits was bred by the } \\
\text { Animal Breeding Department, Cairo University, Giza, } \\
\text { Egypt attempting to construct a breed of uniform } \\
\text { characters . These rabbits were of different colours and } \\
\text { sizes. Colours were }\end{array}$ \\
\hline Golden Montazah & Chicken & $\begin{array}{l}\text { This is a cross between the RIR and Dokki4 (Dokki4 is } \\
\text { a cross between Fayoumi and Barred Plymouth Rock) } \\
\text { and has been developed at Montazah Poultry Research } \\
\text { Station of APRI, Ministry of Agriculture. This } \\
\text { composite has been stabilized over } 10 \text { years. }\end{array}$ \\
\hline Hassawi & Ass & Variety of Egyptian \\
\hline Hawara & Chicken & Autochthonous, derived breed. \\
\hline Ibeidi & Sheep & Descended from Beni Ibeid in El-Minya, Upper Egypt \\
\hline Inshas & Chicken & Autochthonous, derived breed. \\
\hline Kanzi & Sheep & Locally adapted breed \\
\hline Kurassi & Sheep & $\begin{array}{l}\text { Originated in Abo-Karkas in Upper Egypt: similar to } \\
\text { Dongola }\end{array}$ \\
\hline Maenit & Sheep & Locally adapted breed \\
\hline Mahalla 85 & Turkey & Locally adopted breed \\
\hline Maltese & Pigeon & \\
\hline Mandarah & Chicken & $\begin{array}{l}\text { It was developed by Montazah Poultry Research } \\
\text { Station of APRI: named after a district near Alexandria } \\
\text { and is a cross between Alex male and Dokki } 4 \text { female. } \\
\text { It has stabilized for over } 10 \text { years. The Alexandria } \\
\text { strain is a } 4 \text {-way cross of Plymouth, RIR, WL and } \\
\text { variety of Egyptian, with low Zebu influence }\end{array}$ \\
\hline Masri & Goose (domestic) & locally adapted breed \\
\hline Matrouh & Chicken & $\begin{array}{l}\text { It is a cross between the White Leghorn and } \\
\text { Dokki } 4 \text {. It is named after the Matrouh } \\
\text { Governorate and was developed at Borg El-Arab } \\
\text { Poultry Research Station of APRI, Ministry of } \\
\text { Agriculture. The composite has been stabilized } \\
\text { over } 10 \text { years }\end{array}$ \\
\hline Matrouh Gabali & Rabbit & locally adapted breed \\
\hline Menufi & Cattle & variety of Egypt Baladi \\
\hline
\end{tabular}




\begin{tabular}{|c|c|c|}
\hline Breed & Species & Origin \\
\hline Minufi & Buffalo & variety of Egypt Baladi $=$ Monoufi \\
\hline Montazah Silver & Chicken & autochthonous, derived breed. \\
\hline Mowalled & Dromedary & $\begin{array}{l}\text { Mowalled literally means hybrid. The breed is a } \\
\text { composite of Maghrabi and Fellahi. }\end{array}$ \\
\hline Ossimi & Sheep & originated in Ossim, Giza Governorate \\
\hline Qattawi & Pigeon & \\
\hline Rahmani & Sheep & $\begin{array}{l}\text { This breed originated in northern Syria and } \\
\text { northern Turkey and was introduced into Egypt in } \\
\text { the 9th century. The original stock is the Red } \\
\text { Karman from Turkey. }\end{array}$ \\
\hline Roumi & Pigeon & \\
\hline Saeidi & Ass & Locally adapted breed \\
\hline Saeidi & Cattle & Variety of Egyptian with some Zebu blood \\
\hline Saeidi & Sheep & $\begin{array}{l}\text { Locally adapted breed = Saidi, This is the oldest } \\
\text { of the Egyptian breeds found in Upper Egypt. }\end{array}$ \\
\hline Saidi & Buffalo & Variety of Egyptian \\
\hline Saidi & Goat & Some Sudanese Goat influence \\
\hline Salam & Chicken & \\
\hline Sanabawi & Sheep & $\begin{array}{l}\text { Variety of Saidi with smaller tail, originated in } \\
\text { Sanabo, Upper Egypt }\end{array}$ \\
\hline Sharkawi & Goat & $\begin{array}{l}\text { Variety of Egypt Baladi, originated in the Sharkia } \\
\text { Governorate in Lower Egypt }\end{array}$ \\
\hline Shersheer & $\begin{array}{l}\text { Duck } \\
\text { (domestic) }\end{array}$ & \\
\hline Silver Montazah & Chicken & $\begin{array}{l}\text { This breed has been developed by crossing RIR } \\
\text { and Dokki4 and at Montazah Poultry Research } \\
\text { Station of APRI, Ministry of Agriculture. It has } \\
\text { been stabilized over } 10 \text { years. }\end{array}$ \\
\hline Sinai & Chicken & $\begin{array}{l}\text { It could be the result of natural crossing between } \\
\text { unknown native chickens and some foreign } \\
\text { breeds since earlier time. }\end{array}$ \\
\hline Sinai Gabali & Rabbit & Locally adapted breed \\
\hline Sudani & Dromedary & Imported from Sudan \\
\hline Sudani & $\begin{array}{l}\text { Duck } \\
\text { (domestic) }\end{array}$ & Locally adapted breed \\
\hline $\begin{array}{l}\text { Wahati (Arabic }= \\
\text { related to oases) }\end{array}$ & Goat & Originated from the oases in southern Egypt \\
\hline Zaraibi & Goat & $\begin{array}{l}\text { From the Riverine Nubian, southern Egypt: } \\
\text { Nuba is thought to be a progenitor of the } \\
\text { Angola-Nubian goat. Recent surveys showed } \\
\text { that the bred exist in the North East of the Nile } \\
\text { delta not Nuba. }\end{array}$ \\
\hline
\end{tabular}




\section{الموارد الوراثية الحيوانية المزرعية: صحيفة وقائع}

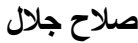

قسم الإنتاج الحيوانس، كلية الزراعة، جامعة عين شعس، ص ب 11241- حدائق شبرا، القاهرة، مصر

تشير الأديبات المصرية و العالمية أن مصر لديها مايزيد على60 سلالة حيو انية زر اعية محلية ومستنبطة.

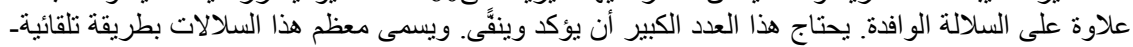

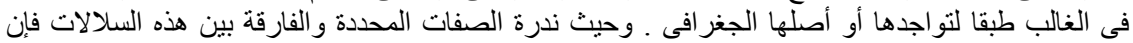

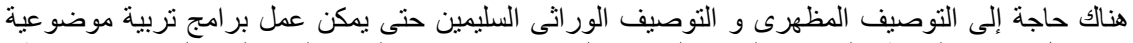

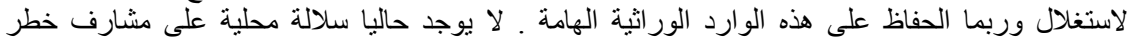

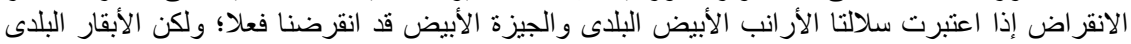

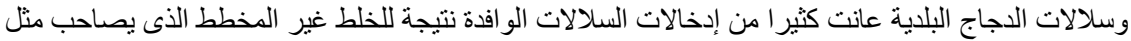

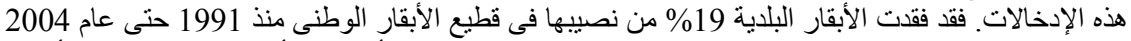

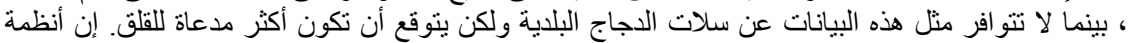

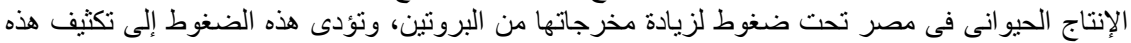

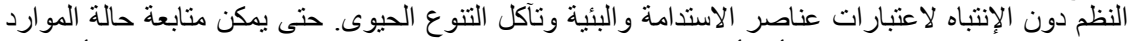

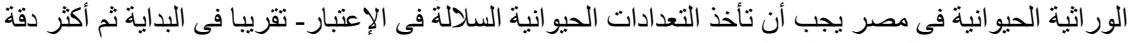

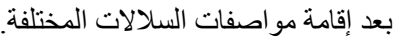
تتصف نظم الإنتاج الحيو انى فى مصر بالغئ الغياب التام تقريبا للتنظيم الثبكى لذوى الثأن فى استخدام وحفظ 